\title{
Membangun Pengelolaan Keuangan dan Entrepreneur Santri di Masa Pandemi Covid Guna Meningkatkan Kemandirian Pondok Pesantren Al-Istiqomah Desa Telaga Waru Kecamatan Labuapi Kabupaten Lombok Barat
}

\author{
Hermanto*, Thatok Asmony, Prayitno Basuki \\ Fakultas Ekonomi dan Bisnis Universitas Mataram, Mataram, Indonesia
}

\section{Article history}

Received: 08-11-2021

Revised: 17-11-2021

Accepted: 24-11-2021

*Corresponding Author:

Hermanto,

Fakultas Ekonomi dan

Bisnis Universitas

Mataram, Mataram,

Indonesia;

Email:

Hermanto57@gmail.com

\begin{abstract}
This counseling and training activity on building financial management and student entrepreneurs during the COVID-19 pandemic in order to increase the independence of the Al-Istiqomah Islamic boarding school in Telaga Waru Village, Labuapi District, West Lombok Regency, aims to provide understanding and training to boarding school administrators and students in West Lombok Regency. . In addition, this training was carried out to provide knowledge to Islamic boarding school administrators and students about the importance of making financial reports and entrepreneurship education during the covid-19 pandemic so that funds from donors can be managed properly and can be managed in the field of entrepreneurship in order to increase the independence of Islamic boarding schools. . In the end, this activity is expected to produce human resources who are able to manage finances and the talents of students in the field of entrepreneurship. This training activity will be aimed at the management of the Al - Istiqomah Islamic Boarding School in Telaga Waru Village, Labuapi District, West Lombok Regency. The implementation of the activity is carried out with an approach to providing material that is relevant to the needs of Islamic boarding school administrators according to PSAK 45 and procedures for building student entrepreneurs during the pandemic. Another hope is that this activity can be a means to carry out community service activities, in particular providing counseling and training on the preparation of financial reports as well as training on building student entrepreneurs during the COVID-19 pandemic.
\end{abstract}

Keywords: financial; management, islamic; boarding

Abtrak: Kegiatan penyuluhan dan pelatihan tentang membangun pengelolaan keuangan dan entrepreneur santri di masa pandemi covid guna meningkatkan kemandirian pondok pesantren Al - Istiqomah Desa Telaga Waru Kecamatan Labuapi Kabupaten Lombok Barat ini bertujuan untuk memberikan pemahaman dan pelatihan kepada pengurus pondok pesantren dan santri yang berada di Kabupaten Lombok Barat. Selain itu, pelatihan ini dilakukan untuk memberikan pengetahuan kepada pengurus pondok pesantren dan santri tentang pentingnya membuat laporan keuangan dan pendidikan kewirausahaan di masa pandemi covid19 sehingga dana dari donatur dapat dikelola dengan baik dan dapat diputar pengelolaannya dalam bidang kewirausahaan demi meningkatkan kemandirian dari pondok pesantren. Pada akhirnya kegiatan ini diharapkan menghasilkan SDM yang mampu mengelola keuangan serta bakat santri di bidang kewirausahaan. Kegiatan pelatihan ini akan ditujukan pada pengurus Pondok Pesantren Al - Istiqomah Desa Telaga Waru Kecamatan Labuapi Kabupaten Lombok Barat. Pelaksanaan kegiatan dilakukan dengan pendekatan pemberian materi yang relevan dengan kebutuhan pengurus pondok pesantren sesuai PSAK 45 dan tata cara membangun entrepreneur santri di masa pandemi. Harapan lain dari kegiatan ini dapat menjadi sarana untuk melaksanakan kegiatan pengabdian kepada masyarakat, khususnya memberikan 
penyuluhan dan pelatihan penyusunan laporan keuangan serta pelatihan tentang membangun entrepreneur santri di masa pandemi covid-19.

Kata Kunci: : pengelolaan; keuangan; islam;Pesantren; Santri

\section{PENDAHULUAN}

Pesantren merupakan sebuah model dan basis pendidikan tertua di Indonesia khususnya bagi agama Islam, sebaiknya terus melakukan revitalisasi institusi agar dapat menjadi salah satu wahana pengembangan kewirausahaan (As'ad, et.al. 2020). Tidak semua lulusan pesantren akan menjadi ulama', kyai, ataupun tuan guru, sehingga, pesantren selain sebagai wadah dari para santri untuk mengkaji literasi keagamaan, ilmu pengetahuan umum, juga perlu mengembangkan minat maupun bakat para santri melalui kegiatan kewirausahaan. Terlebih di masa pandemi saat ini (Adriyani, et. Al. 2018).

Pondok pesantren dikenal dengan kemandirian dalam menjalankan kehidupan berorganisasinya. Hal ini tentunya menjadi dasar dalam mengembangkan minat dan bakat para santri dalam membuat produk bisnis yang tepat agar dapat menentukan target market. Selain itu, hal tersebut menjadi motivasi beberapa pondok pesantren untuk mencoba memadukan sistem pendidikan agama dengan pendidikan kewirausahaan.

Dalam rangka mewujudkan pendidikan yang berkualitas, diperlukan pengelolaan secara menyeluruh terhadap sumber daya yang ada pada pesantren. Salah satu sumber daya yang perlu untuk dikelola secara benar adalah masalah keuangan. Penyusunan laporan keuangan pondok pesantren merupakan bentuk tanggung jawab kepada umat karena secara umum pondok pesantren dibentuk oleh dana umat (Rachmani dan Ainur, 2020). Agar mencapai tujuan-tujuan dalam konsep manajemen pengelolaan keuangan pondok pesantren, dibutuhkan sebuah strategi, yakni memfungsikan secara benar fungsi-fungsi manajemen pengelolaan keuangan seperti perencanaan, pengorganisasian sumber-sumber dana dan pendistribusiannya, penggerak dan penggunaan keuangan, pengawasan dana dan evaluasi anggaran serta mempertanggungjawabkannya. Hal tersebut akan menghasilkan sebuah informasi yang berguna sebagai bahan pertimbangan dalam hal pengambilan keputusan.

Laporan keuangan merupakan output yang berisi informasi akuntansi dari sebuah organisasi dimana hal tersebut dapat digunakan oleh para pemegang kepentingan sebagai dasar dalam hal pengambilan keputusan. Organisasi nirlaba dalam hal ini adalah pondok pesantren memiliki standar dalam pelaporan keuangannya, yakni PSAK 45. Namun, masih banyak pondok pesantren dalam hal pengelolaan keuangannya belum menerapkan PSAK 45.

Pandemi Covid-19 yang terjadi di awal tahun 2020 menyebabkan roda perekonomian sulit berputar. Hampir setengah dari masyarakat yang semula aktif bekerja memutar modal, kini harus berada di rumah. Sebagian dari mereka yang bekerja dari rumah mengandalkan fasilitas dan kemampuan seadanya. Sebagian lainnya dirumahkan, tidak bekerja, bahkan ada yang kehilangan pekerjaan. Sehingga hal tersebut menyebabkan perekonomian yang dialami oleh mereka mengalami keterpurukan di masa pandemi ini.

Pandemi memberikan dampak yang luar biasa bagi organisasi-organisasi baik yang berorientasi laba maupun nirlaba, seperti halnya perekonomian yang berada di lingkungan pesantren. Santri yang pada awalnya selalu beraktivitas di lingkungan asrama, kini harus kembali ke rumah dan belajar dengan fasilitas yang masih terbilang terbatas. Para santri tidak lagi melakukan kegiatan konsumsi di koperasi pesantren atau tempat perniagaan yang berada dalam lingkungan pondok. Akibatnya, perekonomian pesantren harus merangkak, bahkan tidak berjalan sama sekali.

Pondok pesantren Al Istiqomah merupakan salah satu pondok pesantren yang selain organisasinya berorientasi pada pendidikan agama, juga menerapkan sikap mandiri dengan cara 
mengembangkan minat serta bakat para santri di bidang kewirausahaan. Pondok pesantren Al Istiqomah dalam hal pengelolaan keuangan, masih belum mengacu pada PSAK 45. Selain itu, dalam hal kewirausahaan, pondok pesantren AL Istiqomah sudah menyediakan sarana dalam menunjang terlaksananya proses kewirausahaan. Namun, SDM untuk melatih para santri serta program-program dalam bidang kewirausahaan masih belum memadai. Terlebih di masa pandemi saat ini, perekonomian yang tadinya telah berputar di lingkungan pondok pesantren menjadi terhambat. Sehinga, membangun pengelolaan keuangan yang baik serta entrepreneur para santri akan sangat membantu dalma hal meningkatkan kemandirian pondok pesantren Al Istiqomah Desa Telagawaru. Berdasarkan uraian analisis situasi di atas, maka dapat rumuskan sebagai berikut: 1) Pentingnya membangun pengelolaan keuangan yang baik dan sesuai dengan PSAK 45 pada organisasi pondok pesantren terlebih di masa pandemic, dan 2) Perlunya membangun entrepreneur santri yang berguna untuk meningkatkan kemandirian pondok pesantren pada masa pandemi covid- 19 .

\section{METODE}

Bentuk pelaksanaan kegiatan adalah sosialisasi dengan menggunakan metode ceramah untuk menjelaskan materi mengenai pengelolaan keuangan dan entrepreneur santri di masa pandemi covid-19 kepada peserta, yang dilanjutkan dengan sesi tanya jawab/diskusi antara pemateri dan peserta pengabdian. Peserta pengabdian dihadiri oleh 20 peserta Pondok Pesantren Al Istiqomah Telaga Waru Kabupaten Lombok Barat. Sebelum kegiatan pengabdian dilakukan, tim pengabdian telah melakukan pemberitahuan informasi secara langsung kepada ketua Pondok Pesantren Al Istiqomah Telaga Waru yang kemudian disampaikan pada setiap pengurus dan pengelola Ponpes Al Istiqomah.

\section{HASIL DAN PEMBAHASAN}

Kegiatan pengabdian dilakukan di Pondok Pesantren Al Istiqomah Desa Telaga Waru Kecamatan Labuapi Kabupaten Lombok Barat pada hari Selasa 14 September 2021 pada pukul 09.00 WITA. Materi sosialiasi yang disampaikan adalah pengelolaan keuangan dan entrepreneur santri di masa pandemi Covid-19. Kegiatan sosialisasi dilaksanakan dengan mematuhi protokol kesehatan terkait dengan situasi pandemi Covid-19. Secara garis besar, hasil pelaksanaan sosialisasi dapat dirincikan sebagai berikut:

\section{a. Peserta Hadir}

Peserta yang hadir dalam acara sosialisasi berjumlah 20 orang dan hal tersebut telah sesuai dengan jumlah yang di undang. Sehingga dapat disimpulkan bahwa kehadiran peserta telah mencapai target $100 \%$.

\section{b. Ketercapaian Sosialiasi}

Peserta diberikan materi terkait dengan pengelolaan keuangan dan entrepreneur santri di masa pandemi Covid-19. Materi yang diberikan dapat diterima dan diserap dengan baik oleh para peserta dengan dibekali pengetahuan yang diberikan oleh anggota tim sebagai narasumber dalam pelaksanaan kegiatan menjadi penunjang berjalannya kegiatan sosialiasi menjadi kondusif. Selain itu, antusiasme peserta dalam mengikuti pelatihan/ sosialiasi menjadi penunjang lainnya kegiatan berjalan dengan lancar.

\section{c. Ketercapaian Materi}

Kegiatan sosialiasi melibatkan seluruh anggota tim pengabdian kepada masyarakat yang terdiri dari 4 (empat) orang. Kemudian, sesi tanya jawab dilakukan bersamaan dengan penyajian materi sehingga peserta dapat langsung berdiskusi untuk mengajukan pertanyaan maupun menyampaikan berbagai kondisi atau pengalaman yang terdapat di Pondok sesuai dengan situasi Covid-19 kepada narasumber. 


\section{d. Faktor Penghambat}

Faktor penghambat dalam kegiatan ini adalah adanya protocol kesehatan terkait Covid-19 yang mengharuskan peserta menjaga jarak, memakai masker, serta mencuci tangan dan menggunakan hand sanitizer yang disediakan oleh tim pengabdian.

\section{e. Faktor Pendukung}

1. Antusiasme serta komitmen peserta yang tinggi dalam menghadiri sosialiasi meskipun di tengah pandemi Covid-19 menjadi hal positif bagi tim pengabdian kepada masyarakat.

2. Adanya dukungan dari pimpinan Pondok Pesantren sehingga kegiatan sosialisasi dapat berjalan lancar.

3. Kesediaan tuan rumah yaitu Pimpinan Pondok Pesantren Al Istiqomah Desa Telaga Waru untuk menyiapkan tempat bagi terselenggaranya kegiatan sosialisasi sangat membantu tim pengabdian kepada masyarakat.

4. Terjalinnya komunikasi yang baik antara anggota tim sehingga tercipta koordinasi tim ketika proses persiapan, pembagian materi, pelaksanaan, hingga penutupan kegiatan dapat berjalan dengan baik.
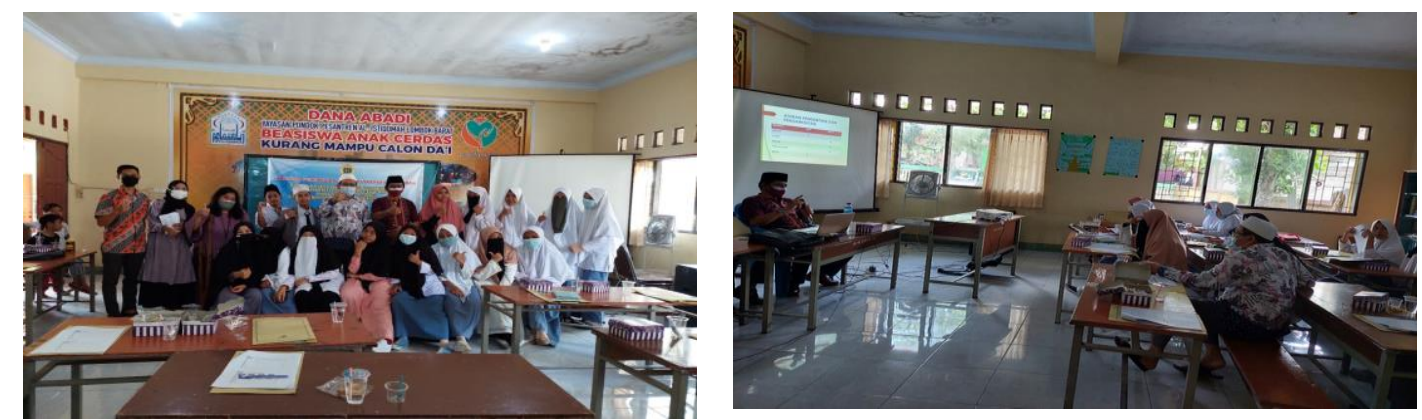

Gambar Kegiatan Pengabbdian tentang Pengelolaan Keuangan dan Entrepreneur Santri di Masa Pandemi Covid Guna Meningkatkan Kemandirian Pondok Pesantren Al Istiqomah Desa Telaga Waru Kabupaten Lombok Barat

\section{KESIMPULAN DAN SARAN}

Berdasarkan hasil pelaksanaan kegiatan sosialisasi dapat diuraikan beberapa hal yaitu adanya pemahaman bagi para pengurus Pondok mengenai pedoman dalam hal membangun pengelolaan keuangan berdasar PSAK 45 yang akan menunjang akuntabilitas serta transparansi keuangan yang dimiliki oleh Pondok Pesantren Al Istiqomah Ds. Telaga Waru Kecamatan Labuapi Kabupaten Lombok Barat. Selain itu, memberikan pengetahuan serta pemahaman bagi para santri mengenai membangun entrepreneur yang berada di Pondok Pesantren Al Istiqomah Ds. Telaga Waru Kecamatan Labuapi Kabupaten Lombok Barat sehingga dapat meningkatkan kemandirian pondok pesantren sebagai organisasi nirlaba.

Saran yang dapat disampaikan penulis yaitu bagi Kementerian Agama Kabupaten Lombok Barat selaku tempat bernaungnya Yayasan Pondok Pesantren yang terdapat di Lombok Barat agar mendukung dan menyediakan fasilitas berupa sarana dan prasarana bagi pondok-pondok untuk meningkatkan praktek entrepreneur. Selain itu, beberapa hal yang masih kurang baik dalam pelaksanaannya akan ditingkatkan pada kegiatan mendatang, yaitu praktik entrepreneur dan pembukuan dalam pembuatan laporan keuangan khusus organisasi nirlaba seperti pondok pesantren.

\section{Ucapan Terima Kasih}

Tim pengabdian mengucapkan terima kasih kepada Lembaga Penelitian dan Pengabdian kepada Masyarakat (LPPM), Badan Pengkajian dan Pengembangan Ekonomi dan Bisnis (BP2EB), dan Fakultas Ekonomi dan Bisnis melalui sumber dana BLU (PNBP) Universitas Mataram yang telah memberi kesempatan dan bantuan kepada tim pengabdian untuk melakukan kegiatan ini 


\section{DAFTAR PUSTAKA}

Adriyani, Zuanita, Ahsan M. Azmi., Wulandari, R Ayu. 2018. Membangun Jiwa Enterpreneurship Santri Melalui Pengembangan Usaha Ekonomi Kreatif. DIMAS - Volume 18, Nomor 1.

As'ad, Ali dan Azizi, Muhammad Hakim. 2020. Pengembangan Manajemen Keuangan Pesatren Balekambang Jepara Dan Amsilati Darul Falah Bangsri Jepara Di Era Digital. Jurnal Tarbawi Vol. 17. No. 1. Januari - Juni 2020 ISSN: 2088-3102.

Ferlinda, Ainur. 2020. Pengaruh Pengetahuan Tentang Pedoman Akuntansi Pesantren Terhadap Penyajian Laporan Keuangan Pesantren. Proceeding of Nation Conference on Accounting and Finance Volume 2 Halaman 39-46.

Niati, Asih, Suhardjo Yohanes, Wijayanti Ratna, dan Hanifah Risti Ulf. 2019. Training of Financial Management and Financial Statement of Boarding School Accounting for Manager at X Boarding School Foundation in Semarang. Jurnal Surya Masyarakat p-ISSN: 2623-0364 Vol. 2 No. 1, November 2019, Hal. 76-79 e-ISSN: 2623-0569.

Norsain, Moh Faisal. 2019. Revitalisasi Pelaporan Keuangan Pondok Pesantren. Jurnal Abdiraja Volume 2 Nomor $1: 6-11$.

Priehadi, DE., Randhy, Agusentoso., Suwanto, Hafis. 2020. Pengeloaan Keuangan Ponpes Dalam Rangka Peningkatan Masyarakat Mandiri Di Panti Asuhan Ikhwaniyah Cinta Yatim Dan Dhuafa. Jurnal Pengabdian Dharma Laksana, Volume 3 Nomor 1: 35-40.

Rachmani, Ferlinda Ainur. 2020. Pengaruh Pengetahuan tentang Pedoman Akuntansi Pesantren terhadap Penyajian Laporan Keuangan Pesantren. Proceeding of National Conference on Accounting \& Finance, Volume 2, 2020 Hal. 39-46.

Suharjono. 2019. Pengelolaan Keuangan Pondok Pesantren. Jurnal STIE Triguna, Volume 8 Nomor 2: 49-62. 